\title{
Comparison of Vertical Light Wooden Constructions Insulated by Straw Bales
}

\author{
Miloslav Kováč \\ Technical University of Košice \\ Civil Engineering Faculty, Institute of Architectural Engineering \\ e-mail: miloslav.kovac@tuke.sk
}

\begin{abstract}
The main task of configuring engineer by designing enclosure construction is to setup performances of the wall to the best options for existing conditions of the structure. Selecting and adjusting bearing elements of perimeter wall is the first step, however appropriateness and position of chosen materials has major influence on technical properties and architectural expression of structure. Besides light vertical constructions (LVC) there are light wooden constructions from glued elements (LPVC), heavy vertical constructions (HVC) and prefabricated vertical constructions (PVC). All types have specifications allowing alternatives in terms of layer structure and bearing elements position. Each type is considered in terms of: structure - 2D drawing and 3D model, thermal insulation, overall heat transfer coefficient, architectural examination.
\end{abstract}

Key words: straw bale, architecture, light construction

\section{Introduction}

There are several types of light vertical wooden constructions used for structures insulated by straw bales. Basic identical attribute is that wood takes all bearing functions, straw bales are imposed between vertical posts and bear just inherent weight. Expansibility of bales meets construction stabilization features by appropriate bale shape and gap dimension. Light constructions are differenced primary by posts properties like, number of elements, dimension, spacing and junction techniques.

\subsection{Initial material parameters}

In the Table 1, there is basic list of materials used in vertical heavy wooden constructions. Data were taken from Slovak standard STN 73 0540-3 (Tab.1). Parameters of straw bale were defined on the ground of former exploratory development work $[3,8,9]$. 
Table 1: Material parameters used in straw constructions according to STN 730540-3 [5]

\begin{tabular}{|l|l|l|l|l|}
\hline Material & $\begin{array}{l}\text { Density } \\
{\left[\mathbf{K g} / \mathbf{m}^{3}\right]}\end{array}$ & $\begin{array}{l}\text { Thermal } \\
\text { conductivity } \boldsymbol{\lambda} \\
{[\mathbf{W} / \mathbf{m} \cdot \mathbf{K}]^{*}}\end{array}$ & $\begin{array}{l}\text { Specific heat } \\
\text { capacity[J/Kg.K] }\end{array}$ & $\begin{array}{l}\text { Water vapor } \\
\text { diffusion } \boldsymbol{\mu}[-]\end{array}$ \\
\hline Straw & 90 & 0,052 & 2090 & 3 \\
\hline Earth plaster & 1600 & 0,7 & 750 & 1,5 \\
\hline Softwood** & 400 & 0,18 & 2510 & 157 \\
\hline Hardwood** & 600 & 0,22 & 2510 & 157 \\
\hline $\begin{array}{l}\text { Oriented strand } \\
\text { board - OSB }\end{array}$ & 800 & 0,11 & 1500 & 12,5 \\
\hline Plasterboard & 750 & 0,22 & 1060 & 9 \\
\hline $\begin{array}{l}\text { Woodfibre } \\
\text { insulation** }\end{array}$ & 230 & 0,046 & 1380 & 5 \\
\hline $\begin{array}{l}\text { Rigid woodfibre } \\
\text { insulation** }\end{array}$ & 400 & 0,098 & 1630 & 12,5 \\
\hline
\end{tabular}

* For perimeter constructions

**Thermal conductivity perpendicularly to the fiber direction

\section{Types of vertical heavy wooden constructions}

\subsection{LVC1 Earth/Earth}

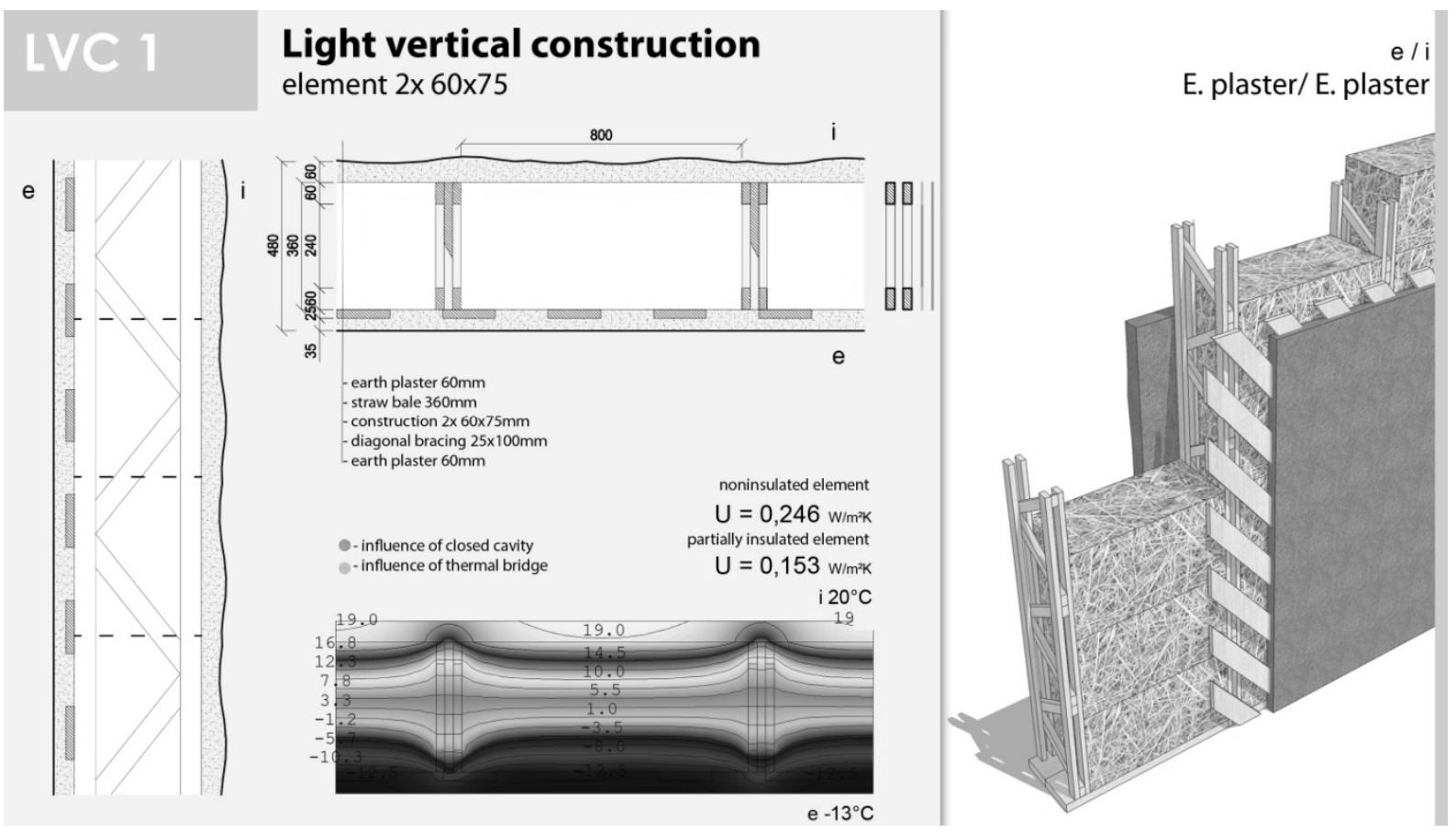

Figure 1: LVC1, author: Miloslav Kováč 


\section{LVC1 Construction description}

System consists of two bearing posts consisting of another two posts fixed one another with diagonal elements (lumber, OSB board) positioned inter posts (Fig.1). LVC1 is one the most elementary system using one type of lumber, used mostly by own builders. Similar system was used by single house in Spišské Podhradie, architect Ing. arch. Boris Hochel and Mgr.art. Bjorn Kierulf.

More sophisticated variant is wooden truss girder bonded with metal strips [3]. Two vertical bearing posts are connected with element of the same dimension (mainly width), that presents simpler shape and lower thermal bridge impact. Generally this systems fall under prefabricated systems, those are easy and swift to assembly.

\section{LVC1 Architectural aspects}

Construction contents bearing elements on both sides that allow free arrangement of incoming materials in perimeter construction and free architectural facade look.

\subsection{LVC2 Wood/Earth}

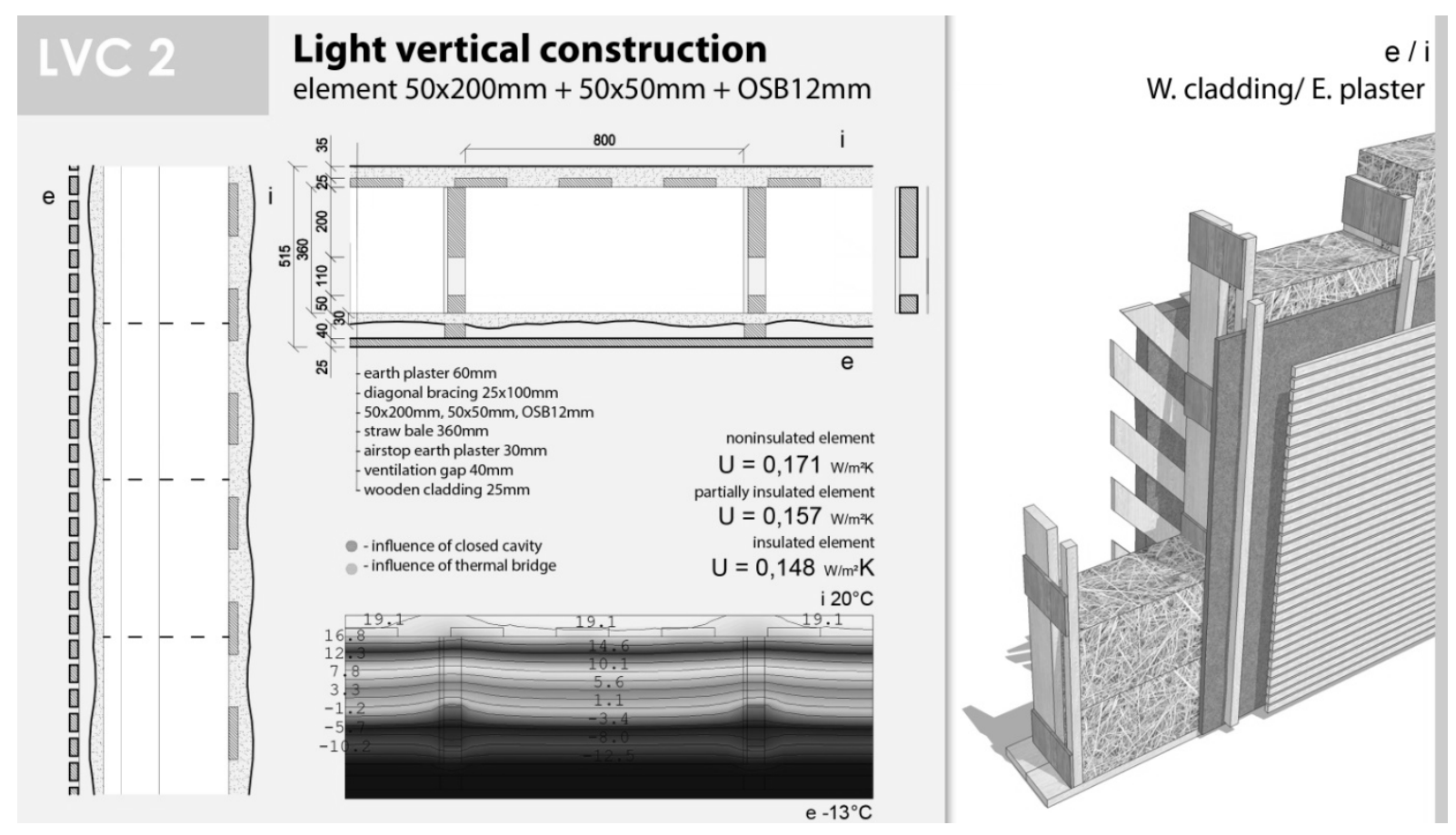

Figure 2: LVC2, author: Miloslav Kováč

\section{LVC2 Construction description}

System consists of two posts fixed one another with horizontal elements (lumber, OSB board). Elements are bearing, the major one is element of general statics system and the minor one bears facade layers [1] (Fig.2). Diagonal bracing is necessary to apply to the major element defining interior/exterior straw bale application. Filling construction with bales from 
the inside is more comfortable due interior possibilities of stocking straw under already assembled roof. Thin earthen plaster on exterior surface of bales creates windstopper together with background for facade lathing. Plaster face is naturally uneven, accordingly sounds more simple to use commercial windstop diffuse open membrane.

\section{LVC2 Architectural aspects}

Construction contents bearing elements on both sides alike LVC1 that allows free arrangement of incoming materials in perimeter construction and free architectural facade look.

\subsection{LVC3 Wood/Earth}

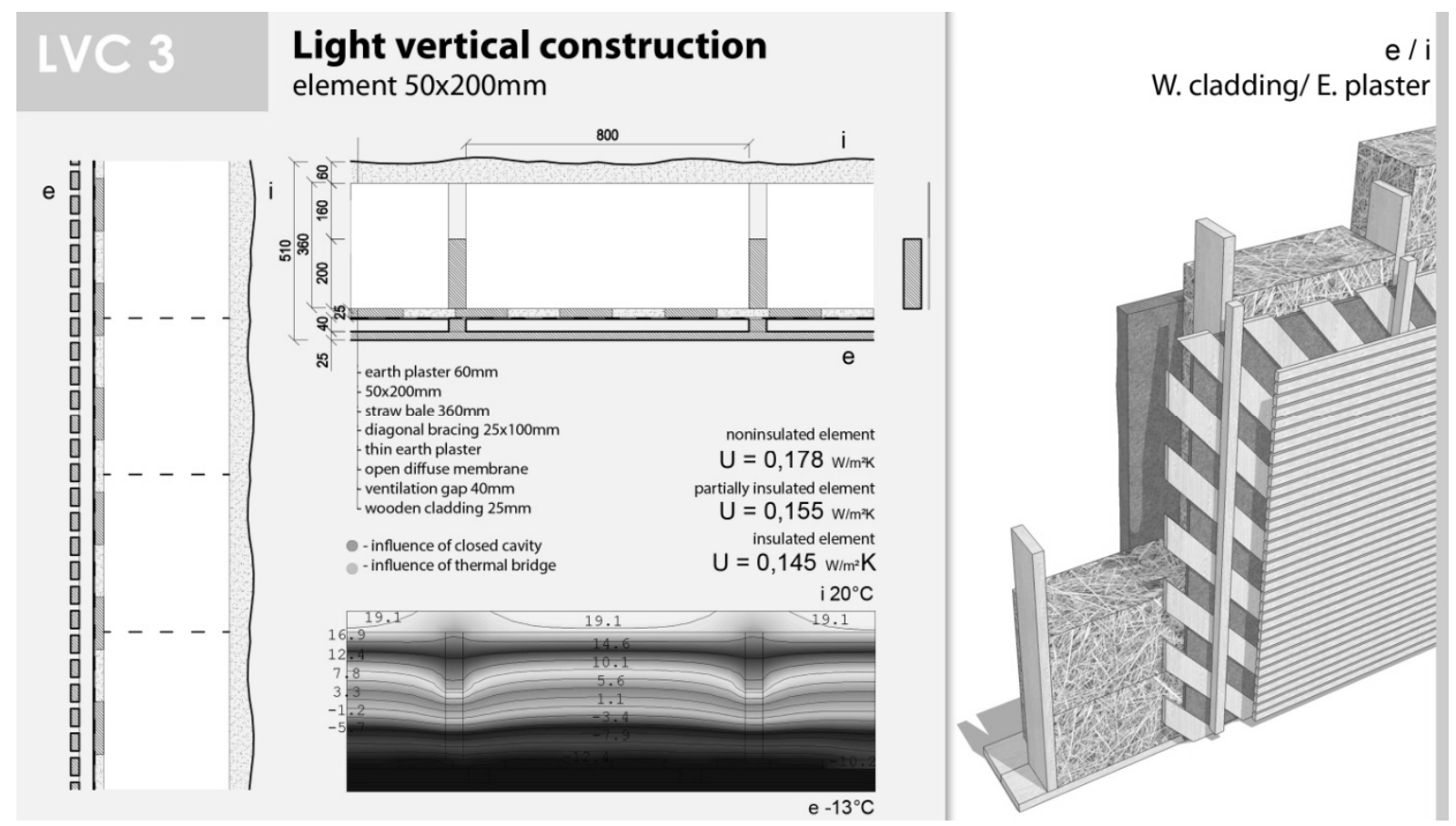

Figure 3: LVC3, author: Miloslav Kováč

\section{LVC3 Construction description}

System consists of one vertical element taking static and potentially facade bearing functions (Fig.3). Depth of element is form $150 \mathrm{~mm}$ to $250 \mathrm{~mm}$ depending up bearing rate [2]. Nonstandard is the depth full element, due the need of usage specific lumber, usually glued one.

\section{LVC3 Architectural aspects}

Position of post essentially determines surface possibilities of finish layer. This system allows lathing anchoring of ventilated facade, installation gap etc. for only one side of the wall. The side excluding anchoring possibilities is predestinated for uneven earth plaster. 


\section{LVC4 Construction description}

This frame system originates in USA in the late 19th century and gradually spread in Europe. Compose of relative dense posts and horizontal straining beams raster, which spacing is usually set to most common large format board materials in $625 \mathrm{~mm}$ and $417 \mathrm{~mm}$ (Fig.4). Application of large format board materials ensure construction bracing and reduce dimensions of bearing elements. Frame system is usually built in wall featuring installation gap or additional insulation layer (blown insulation). Adequate position of boards materials behave like vapor barrier, which is important by using natural materials in need of diffuse open layers composition. LVC4 construction was used on single house in Jablonec nad Nisou (Ing. arch. Jan Márton, Ing. arch. Petr Klápště/ Nature systems. Thin earthen plaster on exterior surface of bales creates windstopper layer.

\section{LVC4 Architectural aspects}

This system primary allows facade setting opportunity for only one side of the wall and excluding anchoring possibilities on exterior side is predestinated for uneven earth plaster like in LVC3. Another way how to create particular facade on whatever straw bale continuing layer, is to apply specific facade bearers. LVC4 contents cables fixed to frame system, and through straw bales anchoring horizontal facade lathing.

\subsection{LVC4 Wood/Earth}

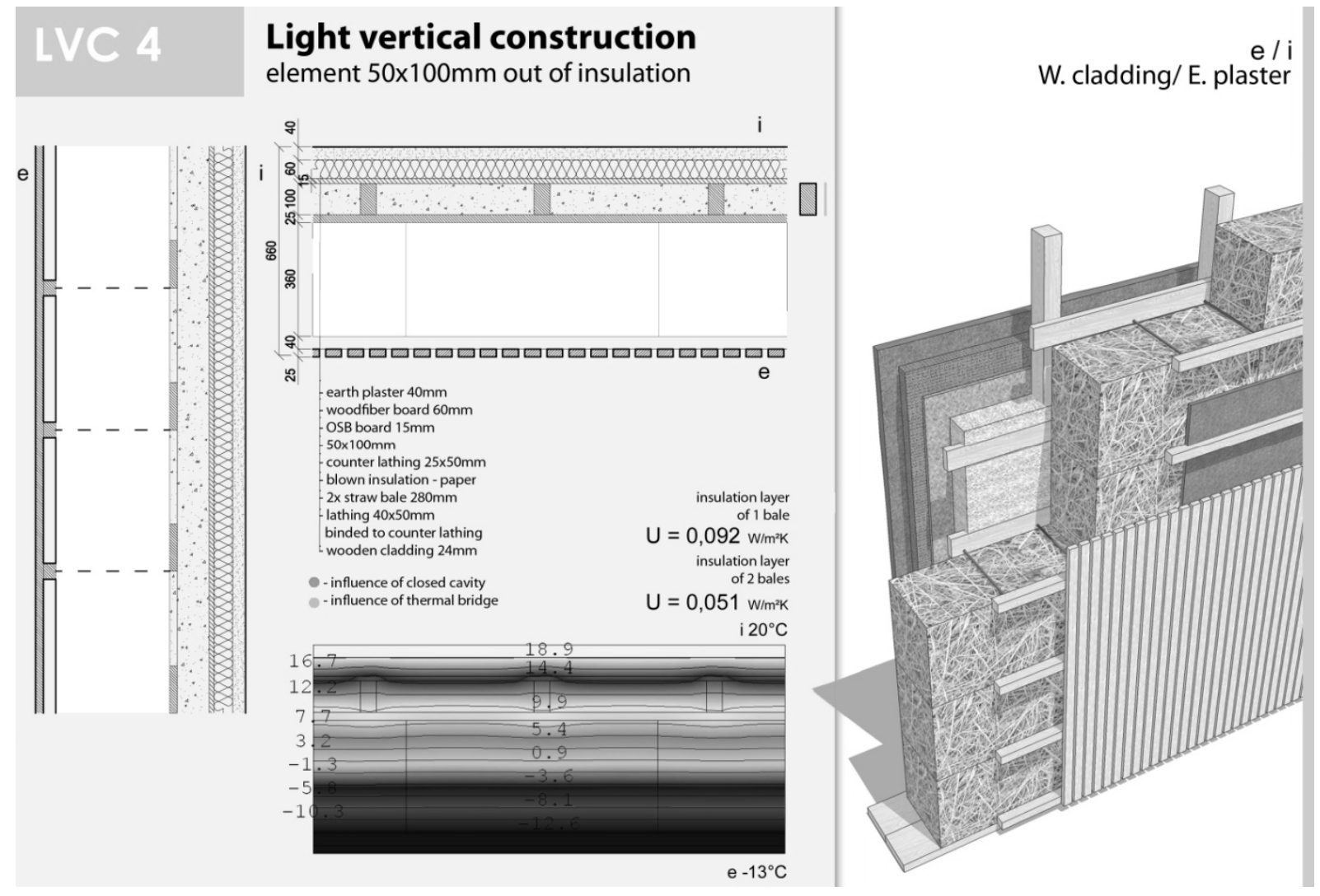

Figure 4: LVC4, author: Miloslav Kováč 


\section{LVC5 Construction description}

Another way to create anchoring possibility is to construct plate cornice that bears load of straw bales. LVC5 is using more massive frame system falling under heavy constructions but the character is typical for light constructions (Fig.5). Example of this approach is located Licancheu, Navidad, Chile, AATA Associate Architects.

\section{LVC5 Architectural aspects}

By using natural windstop layer revealing character of insulation material is possible to consider transparent facade facing. It is meeting constructional standards and architectural specifications in natural contexts.

\subsection{LVC5Transparent/Lime plaster}

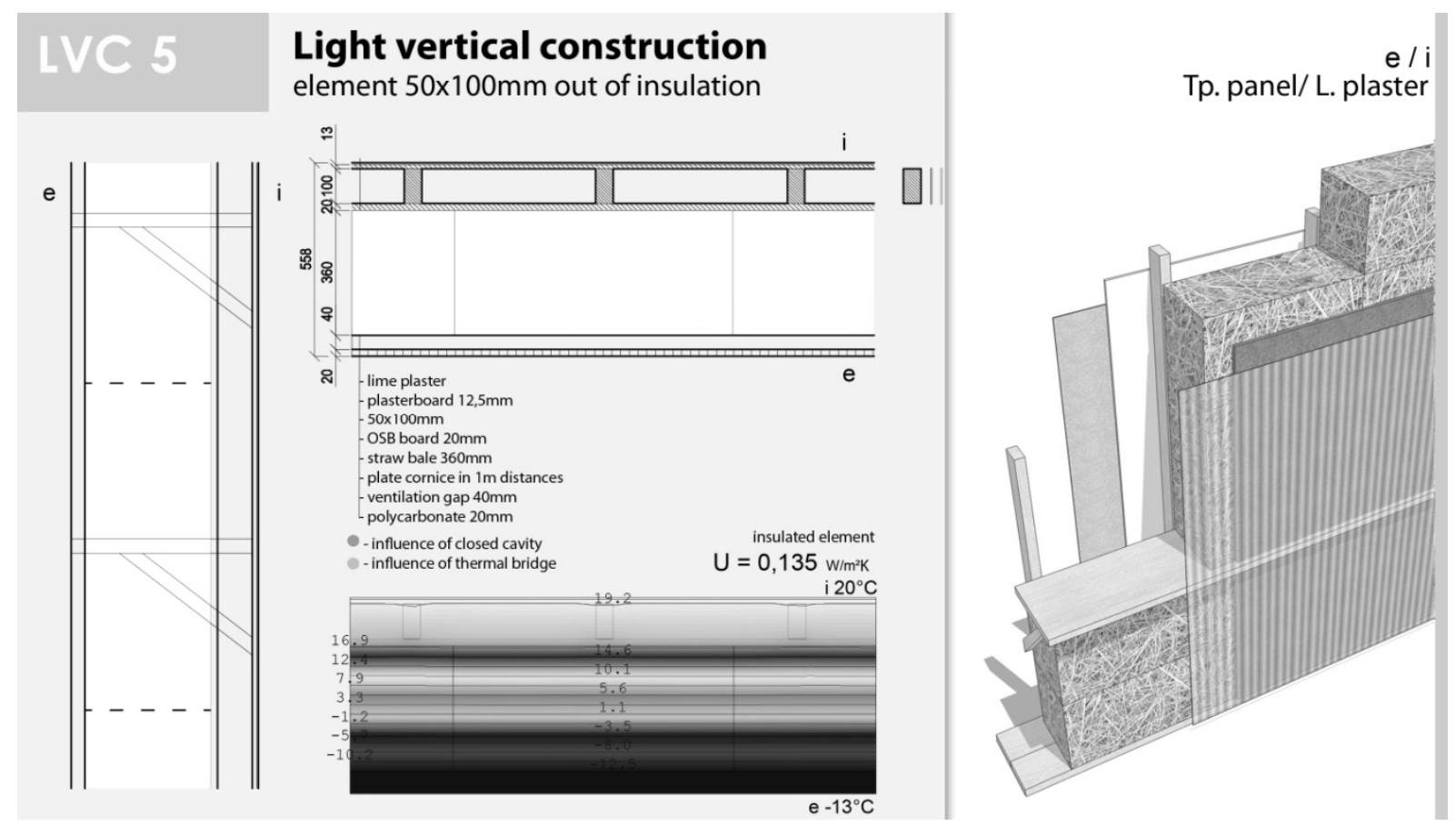

Figure 5: LVC5, author: Miloslav Kováč

\section{Conclusion}

\section{Physical parameters}

The Tab.2 (calculated values) in achieving required value $\mathrm{U} 0,15 \mathrm{~W} / \mathrm{m}^{2} \mathrm{~K}$ of $\mathrm{STN} 730540$ (Table 3), shows necessity of well insulated cavities in light constructions elements and apparently additional insulation (usually fibrewood board). Presence of wooden element in insulation layer makes unable to reach required values, while constructions with bearing elements out of insulation layer are at required intervals (values around $0,14 \mathrm{~W} / \mathrm{m}^{2} \mathrm{~K}$ ). Construction LVC1 according to its basic nature is not convenient for well insulated structure. 
On the other hand constructions LVC4 and LVC5 with eliminated thermal bridges especially in two rows are advantageous solution due option of excessive usage of cheap insulation without increased expenses for wooden bearing system [9].

\section{Narrow openings and disposition}

Light vertical constructions disable wide span openings in perimeter wall without specific arrangement [8]. Architectural disposition is likely to be in regular raster according to visible openings in system of facade.

\section{Construction exposure}

Light constructions are young contemporary wooden-saving systems, which usually didn't allow construction exposure due composition of layers and unattractive natural of thin lumber or OSB board. Also overlapping construction means more thermal bridge problems precondition [6].

\section{Flanning shape}

Constructions LVC1 and LVC2 creates narrow boundaries of window flanning. LVC3 situated on one side of wall allows shaping of opposite flanning and middle position allows partial shaping of both flannings [7]. LVC4 and LVC5 are more liberal for flanning design by using appropriate window frame according to position of wall elements.

\section{Material possibilities}

Light constructions are open for all facade material solutions.

Table 2: Table of light vertical constructions parameters

\begin{tabular}{|c|c|c|c|c|c|}
\hline Construction & $\begin{array}{l}\text { Thicknes } \\
\text { s[mm] }\end{array}$ & $\begin{array}{l}\text { Num. of } \\
\text { materials }\end{array}$ & $\begin{array}{l}\text { Depth of } \\
\text { cavity }[\mathrm{mm}]\end{array}$ & $\begin{array}{l}\text { Thermal } \\
\text { transmittance } U \\
{[\mathrm{~W} / \mathrm{m} . \mathrm{K}]}\end{array}$ & $\begin{array}{l}\text { Average } U \\
\text { value }\end{array}$ \\
\hline LVC1 n & 480 & 5 & 360 & 0,246 & \multirow{2}{*}{0,2} \\
\hline LVC1 p & 480 & 5 & 360 & 0,153 & \\
\hline LVC2 n & 515 & 7 & 110 & 0,171 & \multirow{3}{*}{0,159} \\
\hline LVC2 p & 515 & 7 & 110 & 0,157 & \\
\hline LVC2 i & 515 & 7 & 110 & 0,148 & \\
\hline LVC3 n & 510 & 8 & 160 & 0,178 & \multirow{3}{*}{0,159} \\
\hline LVC3 p & 510 & 8 & 160 & 0,155 & \\
\hline LVC3 i & 510 & 8 & 160 & 0,145 & \\
\hline LVC4 sb1 & 660 & 9 & - & 0,092 & 0,092 \\
\hline LVC4 sb2 & 660 & 9 & - & 0,051 & 0,051 \\
\hline LVC5 & 560 & 6 & - & 0,135 & 0,135 \\
\hline
\end{tabular}

$\mathrm{n}$ - noninsulated cavity of construction element (thermal bridge)

$\mathrm{p}$ - partially insulated cavity of construction element (thermal bridge)

$\mathrm{i}$ - insulated cavity of construction element (thermal bridge)

sb1 - insulation layer consisting of 1 straw bale row

$\mathrm{sb} 2$ - insulation layer consisting of 2 straw bale rows 
Table 3: Requirements for thermal and constructive parameters in STN 730540 [4]

\begin{tabular}{|c|c|c|c|c|}
\hline \multirow[b]{2}{*}{ Construction } & \multicolumn{4}{|c|}{ Thermal transmittance $W /\left(m^{2} K\right)$} \\
\hline & $\begin{array}{l}\text { Maximal } \\
\text { value } \\
\mathbf{U}_{\max }\end{array}$ & $\begin{array}{l}\text { Normalized } \\
\text { required } \\
\text { value } U_{N}\end{array}$ & $\begin{array}{l}\text { Advised } \\
\text { value } U_{\mathrm{r} 1}\end{array}$ & $\begin{array}{l}\text { Destined } \\
\text { demanding } \\
\text { valueU }_{\mathrm{r} 2}\end{array}$ \\
\hline $\begin{array}{l}\text { Perimeter wall and sloped } \\
\text { roof over dwelling space in } \\
\text { slope }>45^{\circ}\end{array}$ & 0,46 & 0,32 & 0,22 & 0,15 \\
\hline Flat and slope roof $\leq 45^{\circ}$ & 0,30 & 0,20 & 0,10 & 0,10 \\
\hline $\begin{array}{l}\text { Ceiling over exterior } \\
\text { environment }\end{array}$ & 0,30 & 0,20 & 0,10 & 0,10 \\
\hline Ceiling under heatless space & 0,35 & 0,25 & 0,15 & 0,15 \\
\hline
\end{tabular}

\section{References}

[1] GRMELA, D. (2012). Ekologické stavitelství. Brno: VUT v Brne.

[2] GRMELA, D. (2008). Využití slaměných balíků ve stavebních konstrukcích. www.slamak.info. [online]. [cit. 20.04.2015]. http://www.slamak.info/products/vyuziti-slamenych-baliku-vestavebnich-konstrukcich/

[3] CHYBÍK, J. (2009). Přirodni stavebni materiály. Praha:Grada bublishing.

[4] STN 73 0540-2. (2012). Tepelná ochrana budov. Tepelnotechnické vlastnosti stavebných konštrukcií a budov. Čast’ 2: Funkčné požiadavky. Bratislava: SÚTN.

[5] STN 73 0540-3. (2012). Tepelná ochrana budov. Tepelnotechnické vlastnosti stavebných konštrukcií a budov. Čast’ 3: Vlastnosti prostredia a stavebných výrobkov. Bratislava: SÚTN.

[6] KING, B. (2006). Design of Straw Bale Buildings: The State of the Art. San Rafael, CA: Green Building Press.

[7] MAGWOOD, Ch. et al. (2005). More straw bale building. A Complete Guide to Designing and Building with Straw. New Society Publishers.

[8] MÁRTON, J. et. al. (2010). Stavby ze slaměných baliku. Vydané vlastným nákladom.

[9] MINKE, G., MAHLKE, F. (2009). Stavby ze slámy. Ostrava: Hell. 